\title{
Cruising Through Spaces: Exploring the Mediatization of Gay Cruising in the Philippines Randy Jay. C. Solis
}

The emergence of new communications technologies has provided a new space for initiating romantic and sexual relationships among gays who perceive social and physical places to be a traditional space that largely promotes connection among heterosexuals. Now, mobile networking applications like Grindr have made it easier for gay men to "cruise" and meet other men, and are seen to lead to the increasing number of sexual partners, being exposed to risks like sexually transmitted infections (STI), among others. Thus this study, framed within the theory of Mediatization - which critically analyzes the dialectic process in which both media and communications on one hand, and culture and society on the other, mutually shape and change each other in an interactional process - explores the question: How have gays' way of cruising, or the initiation of romantic or sexual relations (among others), in the Philippines been mediatized across history?

Keywords: mediatization, gay cruising, gay men, gay technologies, gay spaces, Philippines

It was the first weekend of September 2016 when a friend and I attended a common friend's photo exhibit held at the Philippine Consulate in Hong Kong. My friend Tony and I were introduced to Barbie, a transwoman academic based in Hong Kong. As soon as we were done with the preliminary introductions, Barbie asked my friend: "So, have you turned on your Grindr or Tinder in our university yet?" Tony replied: "Oh yes! On Tinder, I usually get messages from the "daddies" here. They must think I'm a "twink'"' I just shook my head, waiting for them to say more. Barbie went on to tell Tony: "You have to turn it on now and see new men in this area. You must have exhausted the options around your dormitory since you got here." I was reminded that Grindr, a mobile dating app designed specifically for gay men, only shows the first 100 profiles of men in the vicinity of the cruising app user; beyond that, a user has to pay a subscription fee to be able to see six times more men.

I was intrigued by how gay men nowadays would seem to automatically turn on their apps as soon as they step into a place where they have gone to 
for the first time, to explore more and "new" gay men nearby. It has become so convenient that it may have become an unconscious, borrowing from Marshall McLuhan (1964), extension of their bodies. This is quite different from the gay men in a much earlier SMS study in 2007, who would deliberately play around with random numbers only to be able "hit" a target receiver, willing to become their "text mate" (Solis, 2007). This new observation had me asking: How have gays' way of cruising, or the initiation of romantic or sexual relations (among others), in the Philippines been mediatized across history? To examine this mediatization of gay cruising, I explored a number of questions with my gay participants in this study, following Hepp's (2013) operationalization of mediatization: Who are the actors involved? What is the media ensemble? What are the forms of communication? And what are the consequences of the mediatization of gay cruising?

I initially turned to the concept of Media Ecology, which was built on the Toronto School's Technological/Media Determinism, as the theoretical lens of this study. Neil Postman's (1970) Media Ecology pushed the understanding of human perception, learning, and even "chances of surviving" as occurring beyond the direct experience of humanity within a physical environment and situated human experience as occurring in a symbolic interaction with media and communication as environments: their structure, content, and impacts on people's way of thinking, feeling, and behaving (Postman, 1970). This concept of media as causing human and social changes was earlier developed by Marshall McLuhan (1964) as Technological Determinism. Illustrating this, McLuhan partitioned human history according to the Tribal, Literate, Print, and Electronic Eras, where society was defined according to the dominant communication technology at a particular time, because of its power in altering human perceptions and behaviors (McLuhan called this the "extension of selves"), culture, and society at large. For this study, I wanted to explore how the dominant technologies for cruising across the periods in history invariably caused individual and cultural changes for gay men in the Philippines. While this technological deterministic relationship may be judged as possible through historical tracing, the study does not discount the social construction of technology, that users and their everyday lives and cultural circumstances certainly domesticate, appropriate, and also give meaning to these technologies (Silverstone, 2006). In my exchanges with my informants in this study, while some would attribute their being promiscuous to the ease and pervasiveness of the gays-nearby apps, some also show how they can consciously terminate their dependency on apps to meet other gay men and some would even deliberately appropriate non-gay apps or physical spaces like movie houses into a gay sphere, thereby recognizing their "agency" in 
the physical and virtual "structures" that may facilitate or hamper gay men cruising. Thus, de-emphasizing, but certainly not ignoring, a technological deterministic perspective in this study, I also apply theories of mediation (Silverstone, 2005; Livingstone, 2009). Mediation or mediatization theories emphasize this "dialectical process" in which both communication technology and communicative social practices mutually shape each other in an interactional process.

Andreas Hepp (2013) defined mediatization as "a concept used to analyze critically the interrelation between changes in media and communications on the one hand, and changes in culture and society on the other" (p. 619). To operationalize mediatization in communication research, Hepp suggested the framework of communication figurations-"patterns of processes of communicative interweaving that exist across various media and have a 'thematic framing' that orients communicative action" (p. 623) which consists of four instances: 1) the constellation of actors as the structural basis, 2) thematic framing or the action-guiding topic, 3) forms of communication or the concrete patterns of communication practices involving mass or virtualized media, and 4) media ensemble or the entirety of the media through or in which the communicative figuration exists (pp. 623-624).

Mediatization theories take root in Anthony Gidden's (1984) Structuration Theory which emphasizes the mutual constitution of agents and structures in the creation and reproduction of society: where, in the context of this study, the individual or collective users of physical and mediated spaces (i.e., agents), using Judith Butler's (1990) theory of performativity, enact their gendered and sexual identities, preferences, and gratifications in these spaces, whereas the process of using these spaces is also influenced and shaped by various societal and media structures such as the historical, cultural, political, and economic contexts in the Philippines. I will use the stories of my informants to illustrate that the interactions of the individual, the collective, within and beyond the technological affordances and the cultural and economic structures that constitute gay cruising implicate to the wider cultural issues of gay identity and social emancipation.

\section{Methodology}

I distributed interview questionnaires through email and social media, and conducted personal interviews starting with my personal network and then through snowball sampling: I have asked those who have agreed to participate in my research to forward the questionnaire to at least one more potential informant from their own networks. There were deliberate reasons why this was done as a written interview: 1) I was based in Hong 
Kong at the time of the study, but studying gay men in the Philippines, and 2) I felt that writing at their own space and pace would allow them to be more reflective of their experiences, especially as this life story-approach had my informants look back from when they started to recognize their identity and sexuality, to their experiences of cruising, the transitions from then, to their present situation. For a period of three months, I exchanged emails, Facebook private messages, and some video and phone calls with my respondents. I have also personally interviewed four gay informants here in Hong Kong, whom I have also observed in terms of their behaviors pertaining to cruising, albeit in Hong Kong. I have also conducted followup personal interviews and observation with seven of my participants when I had the chance to visit the Philippines at the time of writing this research.

Going into this research, my positionality as a Filipino gay man came to the fore, as it shaped the potentials and challenges in the construction of my data and analysis. On the one hand, my position as a gay man, familiar to most of my interviewees, have gained me their trust and confidence to share their most intimate stories, although my training as a social science researcher also required me to assure them that I am bound by ethical considerations, particularly that of protecting my participants' identities. Also on one hand, my own cruising experiences as a gay man made me relate to the nuances of my participants' practices; on the other hand, it was my position as a researcher aiming at theorization that located and structured my positionalities to be able to refrain from subscribing to underlying assumptions and personal stakes in "my own gay culture" and to set vantage points to drive my inquiry and critiques in studying my own community.

In total, 36 gay men informants participated in this study. My informants ranged from a young 20-year old student to the oldest, a 52-year old hotel manager. Even without posting a set of criteria for my informants, all of them have experienced cruising or seeking out other gay men for whatever purpose, some more actively than others, providing maximum variation from which I was able to derive a richer analysis. However, my informants collectively display relative affluence as indicated by their professions, mostly managers (software development, BPO operations, IT, training, non-profit, hotel), supervisors, business owners, analysts (actuary, finance, social media), specialists (science research, monitoring and evaluation), teachers (elementary, high school, and college), a high-level executive assistant, a marketing consultant, an HR practitioner, a lawyer, a bank employee, a project staff member, and a university student. Most of them represented gay life stories from Metro Manila, but a number of them came from nearby provinces of Laguna, Rizal, Bulacan, Cavite, Bicol, and farther 
metropolitan cities of Cebu and Zamboanga. While this study presumed some condition of relative affluence as it intended to explore gay cruising using technologies, it does not intend to generalize and recognizes this limitation in my set of informants.

I organize my analysis by first showing a time lapse and the media landscape of gay cruising in the Philippines. To illustrate the dialectic of the changing media and the changing gay culture, I narrate the stories of my informants organized according to emerging themes of mediatized gay cruising.

Whilst this study will show some empowering stories, the gay community in the Philippines remains a marginalized sector. Randolph (personal communication, April 24, 2017), my informant from Cebu, said that if the Philippines were truly LGBT-friendly, then the anti-discrimination bill should have long been passed by Congress and Ang Ladlad (an LGBT political organization consistently vying for a Congressional seat) should have won seats in Congress. He added:

In other words, our society is tolerant of the LGBT, our society is amused by the LGBT, but I think it will still take time and great strides before our society will be fighting for the rights of the LGBT in the same manner that society fights to preserve the freedom of, say, the press.

There are growing debates about how new media are affording Filipino gay people the tools to be more active in emancipating themselves (Austria, 2004; 2007), particularly in pursuing romance and sexuality in modernday society, both for the positive (subversive and emancipatory spaces to meet lovers) and the conceivably unintended negative (the steep rise of HIV cases in the Philippines attributed to online cruising) (Dulay, 2018). This study finds its significance in contributing to this discourse about the position of the gay community in Philippine society. Moreover, I have observed, and my informants have validated this in our conversations, that gays are also discriminatory within their own community, with their fat-, effeminate-, and bottom-shaming, among others, within and beyond these new media platforms. This study aims to be a reflexive material both for the out-group and the members of the in-group, using a historical approach, to see whether the gay community has, in fact, empowered or emancipated itself (or has started to, at least) through, with, and within new media, or has only retransformed itself into something else through the practice of gay cruising. 


\section{Gay Cruising in the Philippines: A Time Lapse}

At least four informants, born in the 1970s or earlier, in this study started to seek men actively before the advent of the Internet in the Philippines. How they met men (gay or otherwise) in the pre-Internet period was highly dependent on their social networks and appropriation of non-gay spaces. Most of them met men through a setup by friends, typically gays too, with someone from their circle of friends. Some of them met gay friends, dates, or sexual partners in constant and prolonged interactions at work, in school, and student or professional organizations. Some would even make instant connections in temporal occasions like social gatherings, rave or dance parties, and out of town trips.

Mon (personal communication, April 30, 2017) shared how he and his friends would cruise before the advent of gay-specific places like Malate and the modern communications technologies available to most gays now. They say that there were three modes or spaces where gay cruising would happen and that these would always involve a bakla (Filipino colloquialism for gay) or the parlorista (gays who work in beauty salons), the effeminate gay who pays straight men for sexual favors in either a parlor/beauty salon, with classmates or peers, or just most anywhere with a random bystander (personal communication, April 30, 2017).

The early 2000s saw the massive boom of clubs and bars that specifically catered to gay men, particularly along Orosa and Nakpil Streets in Malate, Manila, considered as the LGBT gay district of the entire country (Baytan, 2015). Some of the clubs mentioned by the participants in the study include Mint, Joy, Bath, Chelu, Red Banana, O Bar, and Bed. While Dana Collins (2005) would say that this transformation of Malate in the 2000s into a commercial space for gay patrons and a hub for the cosmopolitan lifestyle was caused by "the city-directed measure to erase the history of sex tourism through mass commercial development and a gay entrepreneurial oppositional urban renewal" (p. 186), an informant said that Malate was already a go-to place for gay men as early as the 1970s, particularly for more affluent gays, with discos like Coco Banana, which was popular in that area (Oscar, personal communication, January 7, 2018). Another part of Metro Manila was cited to have a popular club frequented by gay men was Cubao (David, personal communication, April 24, 2017). Palawan 2 caters to gay men coming from areas near Quezon City (like Antipolo, Marikina, and Valenzuela) who find it hard to go all the way to Malate in Manila. These bars typically showcase drag queens in a show and some male bikini contests or go-go dancers before they open the floor for dancing. Other bars feature a dark area in their premises where gay men could cruise and even engage in sex. 
Saunas are also cited as a typical gay cruising space, especially by the gym-going informants (Chris, personal communication, May 1, 2017). The high-end gyms in Metro Manila commonly have a sauna or steam room which clients can use to relax after their workout. This appropriation of a considerably non-gay and non-sexual place into a space for gay cruising and sexual gratification happens in movie houses too, especially those in Recto, Manila, where gays like Jude (personal communication, April 15, 2017) would go to meet someone in the toilet or just sit beside someone in the middle or far corner of the theater, and then maybe move on to a motel around the corner after.

The informants claimed that any place could actually be a cruising space. They would cite malls, cafes or coffee shops, public toilets (mostly in malls), the MRT (railway transit), buses, and spas. Troy (personal communication, April 21, 2017) has explored most of these areas: "I invaded cruising areasmovie houses, malls, mall's toilets, bath houses, and anywhere I can find treasures ... [one mall in Ortigas] is known as a cruising area." Two relatively fresh university graduates talked about the cruising phenomenon in school campuses and restrooms. Oscar (personal communication, January 7, 2018), the oldest informant in this study, said that owning his first car at the start of the year 2000 made him "more mobile and meet more men" literally on the streets.

Van (personal communication, April 15, 2018) identified the telephone as the first communications technology that he used to be able to seek other men by dialling random numbers and waiting for a man to pick up. He added that gays would actually use this "party line when telephone lines just cross randomly and you can get to cruise other men." Although his telephone interactions remained online, Van said that he's heard of friends who have met strangers and had sex using random telephone calls.

Francis (personal communication, April 25, 2017) talked about magazines and tabloids posting personal ads of people who would want to meet other men before there were online technologies. Meeting by responding to personal ads in tabloids became even more widespread with the popularization of cell phones at the start of the 2000s. Francis shared experiences of how texting, in connection with the tabloid ads, led him to meeting a sex partner and a boyfriend in the past. Justin (personal communication, April 23, 2017), on the other hand, shared his first sexual encounter with another man after being the receiver of such random SMS cruising.

Almost immediately after the rise in popularity of mobile phones at the start of 2000, service providers saw the potential of the convergence of the texting technology with television, allowing people now to cruise in real- 
time via the mass medium with the birth of the Text TVs like LinkTV and TheLounge (cf. Garcia, 2002).

Around this time, to boost mobile subscription in the Philippines and to build their respective communities, the two largest mobile network providers, Smart and Globe launched the Smart Zed and GlobExplore (Trivedi, 2003). By being a member, Ali (personal communication, April 13, 2017) was able to share his age, sex, and location, and through the phone menu navigate to meet up with random people, for a fee of 2.50 pesos per transaction.

Around this same time, analog cell phones were slowly transforming into more digital devices, with the introduction of the GPRS or $2 \mathrm{G}$ phones which were capable of mobile Internet. A little before that, cell phones could connect with other phones for free, via Bluetooth technology. Turning on one's Bluetooth allowed other cell phone users to search other phones nearby. David (personal communication, April 24, 2017) said that gay men took advantage of this early form of cruising people nearby by posting one's cell phone number on his device name, for example: "sexmeuprighthererightnow09171231234." A similar strategy was used when the Blackberry Messenger, introduced in 2005, although exclusive to Blackberry cell phone owners, allowed users to exchange messages and multimedia files privately or via a chat group (Alexander, 2019).

The potentials of the mobile phone as a romancing and sexuality gadget were early on explored by Raul Pertierra and colleagues (2002) and Randy Jay Solis (2007) wherein they found that homosexuals took advantage of the affordances and "characteristics" of the cellular technology to meet other men. A young, curious bisexual took advantage of the texting technology's affordability and convergence with television by meeting up with persons of the same sex whom he connected with through the Text TV chatrooms (Pertierra, et al., 2002) while another homosexual shared how he took advantage of the autonomy and privacy of the texting technology to forge unconventional same-sex affairs and even "sex text" (Solis, 2007).

But even before the appropriation of the earlier versions of the mobile phones for gay cruising, starting in the late 1990s, mIRC was the most popular way of cruising for gay men, for those who had access to a computer and Internet connection. Although requiring some knowledge of scripting language, ordinary people, including gay men, generally picked up on the group chat technology. Other group chat technologies, with better interface and did not demand some skills in scripting language, were Yahoo! and MSN Messengers. Nico (personal communication, April 11, 2017) shared: 
I found it out through mIRC, that Yahoo Messenger was used by almost everyone at the time, so I joined it too. There are chat rooms that are created for specific groups that you want to join in (e.g., gay, Latino, c2c groups). It started there and group meet ups were scheduled through that too.

ICQ, developed around the same time as the IRC, allowed for more one-onone instant messaging.

In 2000, Pinoyexchange.com, another form of group chat, only less realtime and in the form of an online bulletin discussion board, became popular where gay men could put up gay-related forums and interact with each other. Roger (personal communication, April 12, 2017), who once served as a moderator for the site, said that communities were formed through these interactions, and eyeballs or meet-ups were organized either just between two chatters or among members of the forum-communities. Similar to Pinoyexchange.com, Craigslist is a worldwide classified ads website, which allows users to specify their posts in certain regions, countries, and cities, according to sections and discussion forums devoted to particular products and services. Using the personals section "men seeking men," gay men also use this site to search and meet other men (Jay, personal communication, April 25, 2017).

Computer mediated communications' potentials to build communities and empower gay men were explored by Fernando Austria in 2007. Comparing the stories from my informants and the findings of Austria reveals that nothing much has changed. The same "categories" of gay men, in Austria's study: discreet, curious, men who have sex with men (MSM), undecided, questioning, and closet gays, were still mentioned by the informants at present. In Austria's study, Yahoo! Groups allowed for virtual communities of these gay men in the Philippines to be built, founded on the collective good of needs gratification: diversion, personal relationships, personal identity, and surveillance. He traced that the personal behaviors potentially lead to group identification, to active participation, and eventually to the promise of social change in the real world. While this study was mostly about building virtual communities and the corollary empowerment of Filipino gays, and these groups proved to have been avenues for gay men to cruise as well, its implications on this study show that building gay communities and gay cruising may be viewed as gay practices that have wider implications on gay identity and its position in the society.

The informants in this study said that around 2002 to 2004 saw the boom of online gay cruising with the development of social networking websites such as Friendster, MySpace, Multiply, and social networking sites 
specifically for gay men such as Guys4men (now Planetromeo), Manjam, Downelink. Gay.com and Gaydar.co.uk are much older websites, launched in the late 1990s but were still widely used by the informants during this time. These social networking sites allowed users to post a profile of themselves, share photos and videos, and even blog entries; these were the earlier forms of Facebook. Gay social networking sites were more functional in terms of assisting gay men to seek other men, allowing for detailed search according to location, age, whether users have photos or not, what they are looking for in the site (chat, friends, dates, sex, relationship, activity partners, etc.), ethnicity, height, weight, body type, sexual preference, and the likes. Now, with the popularity of the geosocial networking apps, these Internet-based social networking websites have added features like locating people nearby and online or within a certain radius from the user. Moreover, websites like Planetromeo have also developed a mobile platform to compete with more recent apps like Grindr (2009), Scruff (2010), BoyAhoy (2010), Growlr (2010), Jack'd (2010), Hornet (2011), and Blued (2012), which started to gain popularity among gay men, and caused quite a stir among the general public, after the introduction of smartphones like iPhones and Android around 2007 and 2008. A particular chat website, not specifically targeting gay men and is popular among students, Omegle, launched in 2009, allows random and anonymous chatting with a stranger. While mIRC, Yahoo, and Blackberry Messengers are essentially group chatrooms where one can interact with a group of guys at the same time, Grindr and the more recent gay mobile dating apps are individual profile-based and one can choose to interact with people through direct or private messaging. The mobile apps now are location-based, meaning, gay men can search for men nearby and chat with them privately, unlike before when guys4men and similar websites only allowed gay men to tag themselves in a city or location, allowing one to be searched in that area, but not proximity-based.

Facebook, launched in 2004, which is perhaps the most popular, surviving social networking site, is merely an updated version of the former Friendster, MySpace, and Multiply. Its subsidiary, Instagram, launched in 2010, is now perhaps the most popular mobile and desk app for photo sharing. Twitter, launched in 2006, is another popular social networking app, a form of micro-blogging, allowing users to post tweets or messages of 280 characters (initially just 140 before 2017) and reply, react, and/or share these tweets. Informants in this study said that, like in the earlier Friendster, MySpace, and Multiply, gay men also use Facebook, Instagram, and Twitter to cruise for other men.

Tinder is another mobile dating app launched in 2012, although not exclusively for gay men, but is appropriated by gay men, including some of 
my informants, for cruising by limiting the app's discovery settings to just men. WeChat, Line, and Viber are not so much social networking apps as they are communication apps, but as Chris (personal communication, May 1,2017 ) would explain, gay men would also appropriate these technologies to cruise for other men: "Because of the same technology Grindr is using, GPS, you can locate the nearest people in your location and you can filter it by gender. So if a man messages you, which is unusual, most likely they are gay too. You can also post a status indicating what you want (e.g., looking for fun) and that is a sign for other gay people using the same app to message you." Skype and Zoom, providing video chat and conferencing services, are also being used by gay men "to engage in pretend sex and derive carnal fulfilment," according to Ronan (personal communication, April 18, 2017).

The informants in the study said that while it is convenient to look at physical/social spaces and the mediated spaces separately, most of them are conscious about the hybridity of the two spheres. They typically point out that gay men make friends on social media but that they are also being introduced to common friends or set up for dates outside of these social media, mostly through hangouts, sports activities, out of town trips, or videoke parties. David (personal communication, April 24, 2017) also cited that organizing gay social events and inviting participants to these events use online chatrooms, forums in Pinoyexchange, and social media:

Some people on these gay sites (i.e., Planetromeo) organize real life events for the members of the website. They might do a general invite or an invitation-only event for people they want to attend. I've received some of these in the past and it usually states what is expected of people who will show up to these events. These are usually held in private residences or hotel rooms.

Almost all of the informants claimed that in the end, all mediated interactions culminate in a face-to-face meeting, if only to consummate their purpose in meeting online.

Now, what are the typical reasons why gay men cruise online and/or in social spaces? The informants mentioned five main purposes for cruising: 1) for romantic dates that may lead to; 2) finding love or a partner for a serious relationship; 3) sex, including online sex (phone, cam2cam); 4) for networking or activity partners: someone to do things with like drinking, sports, going to the beach, partying in clubs; and 5) friendship. Those who are looking for networking or activity partners are mostly those curious about how it is to be gay: what they do, where they go, what they talk about. While those looking for friends have no gay friends in their circles and that 
they are looking for like-minded individuals to share common interests and experiences with as gays. Moreover, informants like Justin, Billy, and Nico stressed that while they end up cruising in instances when they go out partying in gay clubs or receive friend requests via Facebook, they were really not actively seeking to meet other men. These men were the typically the ones who receive invitations rather than initiate contacts with other men.

\section{Mediatization of Gay Cruising Getting sex-crazed and romanticizing the traditional}

Some of the informants explicitly said that it was the use of cruising technologies that caused them to be more sex-driven. Chris (personal communication, May 1, 2017) said that when he was younger, he preferred love to sex, but that he became more promiscuous as he got older. Mac (personal communication, April 13, 2017) shared how the environment of cruising can cause this:

Initially, the purpose was to chat, meet, and find a date for a possible long-term relationship. I was young, very optimistic, and romantic then; so my intention to meet men is really to establish a relationship and find a partner. However, upon using PR for some time, I realized that members' main purpose is to mainly engage in sexual activities with other men. While my initial top priority was to make connections for a possible long-term relationship, it shifted to sexual purposes as the platform and its members are not there for LTR.

Sherwin (personal communication, May 2, 2017) believes that Filipino gay men have become more sexually aggressive at present, which makes it riskier for gay men in terms of sexual behaviors. Ali (personal communication, April 13, 2017) shared this belief too. He fears that as technologies for cruising are now prevalent, it could also lead to gay men getting more susceptible to getting sick: "Not too long ago, it was still very fun and pleasurable meeting other men, having unprotected sex was not an issue at all. Nowadays, I have to be really careful."

The correlation between mobile dating apps use and the increase in STI and HIV risk has received growing attention among scholars and health workers alike. In fact, separate studies in the United States and Australia have validated that the use of geosocial networking apps or mobile phones in general by men who seek sex with other men increase their number of sexual partners as well as their likelihood or prevalence of being diagnosed 
with STI (Lehmiller \& Ioerger, 2014; Hull, Mao, Prestage, Zablotska, de Wit, \& Holt, 2016). In a study by Kane Race (2015), the author showed how these mobile apps and online dating have provided for an infrastructure that allowed new modes of sexual encounter, particularly that of party and play (PNP) or the use of recreational drugs for sexual play. These "chemical sex" encounters are seen to increase even further the likelihood of contracting STIs. It is because of this emergence, if not prevalence, that the author aimed to offer the study as a way to help both users and health (promotion) professionals navigate around this phenomenon.

For the older informants of the study, there seems to be a trend in terms of how they described their history of cruising. Adam (personal communication, April 25, 2017) called this the "puppy love-sex-settling down cycle." They typically start out with the curiosity phase of wanting to identify with other gay men, to satisfying sexual desires, and then to establishing more meaningful and lasting relationships. Knowing that everyone does indeed go through this cycle seems to negate the idea of technologies making its users just sex-crazed, but this is not to discount the admission of some of the older informants that some of them have really not moved on to the "settling down" stage as they are still enjoying meeting more gay men for sex.

But while some have confessed that they remain "single and who still mingle" because they made a conscious decision about this, others have merely become disillusioned by love. Ali, 30 years old, who was for a time engaged in an "open relationship" where he and his partner agreed to still be able to have strictly sexual relations with other men, and would even use gay apps while they were at it, said that while it is much easier to find a romantic relationship for gay men now, it has also become much easier to lose the same (personal communication, April 13, 2017). Chris, 31, said that finding love nowadays is challenging because, "Why would someone stick around if they can have anyone they want?" (personal communication, May 1, 2017). Seeing the same "trend" now, Lee, 34, adjusted his strategies in cruising: "I am more analytical and logical now when it comes to dating other guys, I guess due to the fact that it is more difficult to meet guys who will love and remain loyal to you" (personal communication, April 16, 2017). Jay (personal communication, April 25, 2017), only 26 years old, also shared:

I've pretty much given up on the idea of finding a partner in that space [dating apps] ... I've always held the idea that I would one day stop these interactions because they're laced with impure intentions. It has become a fantasy among friends that we'd meet someone the good old-fashioned 
way, like our hetero counterparts: at a party, introduced by a friend of a friend, etc. I'm still holding on to that. In a way, I'm still holding on to the idea of meeting someone "organically" without the need for technology, no matter how backward that seems.

This romanticizing of in-person meeting for a romantic or any meaningful relationship is palpable among the informants. The "traditional way" as most of them would put it, is said to be more proper, reliable, secure, and meaningful.

\section{Managing saturated selves}

Gay cruising through technologies "is like dating on steroids," Sherwin said (personal communication, May 2, 2017). Informants also noticed that this is not only limited in mediated spaces, but that gay men now get to meet more gay men and have also become aggressive in cruising in bars and clubs. Meanwhile, Ali (personal communication, April 13, 2017), "became more particular when choosing hook-ups since there are a lot of fishes in the ocean." While being more "picky" seems to suggest that a person values one's set of standards, the informants in this study tended to see the idea of "many fish in the ocean" and the corollary capriciousness in an alarming way. As access to cruising channels have increased, looking for a genuine person with the same interests now have become more challenging, and so some informants make sure to develop a solid connection with online matches first before meeting up in person.

The "high standards" that gay men have developed is borne out of the idea that there are better options available out there, and so Bob (personal communication, April 14, 2017) shared that "[i]t has become difficult for me to really meet someone when it comes to potential dates or relationships because most gay people want the perfect man." As for Mac (personal communication, April 13, 2017),

[t]he ease of communicating and finding new men to meet nearby also made me less of a serious relationship-seeking person because of the thought that I can meet another guy who may be better than the one I am dating right now. I still don't want to settle down with someone because there are many others in Grindr.

Kenneth Gergen (1991) foresaw this phenomenon and called this the saturation of the self or social saturation. According to him, technologies in contemporary life have multiplied the quantity and modes of our 
relationships and redefined how we understand ourselves and our abilities in these relationships. While technologies facilitate multiple and sustained connections, allowing the creation of relationships at an accelerated pace, intimacy is considered rushed in this way. Moreover, new forms of relationships emerge as they move from the face-to-face to that of the virtual mode. And so, modernity is beset with the challenge of intensifying and managing emotions in relationships, and superficiality is judged to be an outcome in these modern relationships.

Abe (personal communication, April 14, 2017) thinks that the negative side of cruising online is that gay men have become too fixated on the physical, and yet still, this sense of physicality have helped others become more self-assured and confident. Troy (personal communication, April 21, 2017) agrees with this duality, but that gay men have to learn how to manage this more humanely:

Using technology has its pros and cons of course. In any of these apps, people tend to be superficial. Some would offhand ask for your picture and then decline you immediately. It is an ego booster and at the same time would ruin your confidence. We all have our preference after all. It is a matter of respect. If you don't like each other or maybe not a match, then why beat around the bush? I tell them but of course with gentleness.

Superficiality for the informants also meant the lack of emotionality. Ian (personal communication, May 4, 2017) said that because a breadth of connections is now more accessible, relationships now have become short and impersonal. Mac (personal communication, April 13, 2017) said that people seemed to have created a barrier for deeper emotional understanding due to the number of options one has, and that these are typically just for sexual fun. For Oscar (personal communication, January 7, 2018), there is nothing wrong with this, as some would intentionally not want an intimate or emotional relationship in the first place:

[I]t all depends on how one wants to use these apps. Others say that because of the ease of usage, with how quick one's circle would expand, or the number of [phone] numbers one gathers, that the degree of closeness of the interaction is lessened. Like with any communications tool, it all depends on your purposes and how you want to use the communication ... Does one value quality over quantity or vice versa? It all depends on what we want. 
While the discussions above point to the breadth and depth of gay cruising, speed seems to be another emerging aspect of gay cruising. Lee (personal communication, April 16, 2017) noticed that while gay men now find it easier to meet more people, maintaining these relationships have become challenging because of "the fast and impatient nature technology has instilled in younger people." Roger (personal communication, April 12, 2017) refers to this as the "quickie mentality." This is the same change that Chris (personal communication, May 1, 2017) also noticed about gay men nowadays:

Now, in as short as a day, you already judged the person based on your preference and then move to another one ... Before, you have to really invest time, money, and effort if you really want to get to know someone ... You need to invest on cell phone load, go on dates, court the person, and give gifts.

\section{Marketing selves}

Adam (personal communication, April 25, 2017), a marketing practitioner, looked at gay cruising online as involving marketing strategies:

Positioning and placement are very important to us. Positioning is the way you sell yourself in your market. If you position yourself as smart, conservative, serious one, people who see that as interesting will treat you that way. Hence, if you position yourself as sexually available, open for sexual meet-ups, no-strings attached fun, then your market would ask for the same thing. Placement or the "right tool" is the medium you use to meet your objectives. As I mentioned, I used Grindr for sex, Facebook and Twitter for a more serious note.

He added: "People consume with their eyes. When people post their naked pictures, amateur videos, etc., they become more 'consumable' than the rest of the market. Gay men work out because counterparts are more attracted to gym fit or muscular guys."

This is perhaps the reason why Jay (personal communication, April $25,2017)$, for instance, has become more conscious in terms of presenting himself online and offline. He said that part of why he keeps himself fit by running is that gay men on Grindr put a "premium on looks and physique." He said that this has come to the point that "[g]ay guys can be very mean toward each other. Some gay guys are pressured to keep up with appearances 
in order to find partners. It hasn't been uncommon for me to hear gay friend hitting the gym for 'market value"' For Sherwin (personal communication, May 2, 2017), while he noticed that gay men on Planetromeo tend to value more muscular and masculine men, he took advantage of framing his profile "to reveal himself more":

"I was able to really think how I wanted to project myself in my profile, and I wanted to do it honestly. For instance, my profile indicated that I am quite effeminate so I'm able to filter out guys who are not okay with that. I think this made it easier for us to manage our expectations about one another."

\section{From "gay to straight" to "gay to gay"}

Mike and Mon, before being introduced to the Internet and other gay cruising technologies, grew up thinking that for a gay man to be able to get sexual gratification and love, one had to meet a straight man who was willing to provide for these at a price. Mon (personal communication, April 30, 2017) shared:

Before, when I was a lot younger, my only perspective was you would grow old and die alone as there was no real and romantic love between gay and straight men. But my eyes were opened to a possibility that today, there is a future for gay to gay relationship. That you are not only confined to loving and providing for straight men but rather there is a future for you in loving and providing for men in the same way they would do for you.

Anthropologist Michael Tan (2001) wrote about this too in his ethnographic work on emerging gay communities in the Philippines:

In the beginning, then, there were only bakla and lalake, the "real men." A proper bakla would never have sex with another bakla for that would have been tantamount to lesbianism. A bakla was a 'girl', and 'girls' go for 'real men.' (p. 121)

Mon (personal communication, April 30, 2017) appreciates that gay people as young as teenagers are now exposed to the notion of gay-to-gay relationships because they grew up in a generation when technologies allow them to meet like-minded individuals consensually and without the need to pay for sex or eventual romantic relationships. Although Mike and Mon 
admit that this scheme of gay men paying straight men they meet on the streets for sex is still rampant, the existence of gay clubs and dating apps certainly provides them now with more avenues to meet a spectrum of men, gay and straight included.

\section{Openness to the gay spectrum but also discrimination within}

For the informants in this study, widespread gay cruising has contributed to gay men recognizing and appreciating the "spectrum of gayness" in the Philippines. As Mon and Mike (personal communications, April 24, 2017) showed, to be gay before would mean being the parlorista gay paying straight men for sex and love. Now, Billy (personal communication, April 29, 2017) claimed, "[y]ou can be gay in the closet and still get to hook up with other men. Before [there was only the] stereotypical gay, but now you can't tell metrosexual men and gay men apart." While the bakla, typically seen as the parlorista and effeminate gay man, is of course still a part of the spectrum, David (personal communication, April 24, 2017) expressed that there are more faces to gay men now:

I think Filipino gay men have both stayed the same and changed throughout the years. The Pinoy bakla has been visible in our society since even before I was born. They have been the comedic relief of numerous movies, the sassy hair salon maven, etc. They are still here, and they are a strong part of the gay community in the Philippines. But what has been added is a growing diversity of Filipino men who identify as gay and are living their own lives as they define it to be... Being gay comes in a lot more different packages today than in the past. I guess it is helpful that within the gay umbrella, we have different cliques of gay men who find belongingness and support amongst other men that share similar interests.

While this is so, some spectrum in the "gay umbrella" seems to be favored and promoted more than the others. Homosexuality scholars in the Philippines agree that across history, the identity of the bakla as the cross-dressing effeminate, like the indigenous cross-dressing religious functionaries Babaylan from the precolonial period, is being erased from the narratives and consciousness of the Filipino society (Quintos, 2012; Tan, 2001). The precolonial Filipino homosexual, the asog (hermaphrodite or man who dressed and behaved like a woman), especially during the time of the Catholic Spain colonization, was reconstructed to mean "bakla, or cowardly," and sinful, and is still perpetuated even in contemporary society 
by the Philippine media, as enshrined in the guidelines of the Movie and Television Review and Classification Board (Quintos, 2012). Moreover, Bobby Benedicto (2008b) argues that there is the "desire to imagine the obsolescence" (p. 327) of the bakla, as lower-class, effeminate, and the parlorista, with the emergence of Western-desiring global gay.

While the notion of discrimination in gay history was originally mainly assigned by the larger, conservative, Catholic society in the Philippines, now it has become a dividing issue from within the gay community, for example those of the global gay versus the bakla. According to Randolph (personal communication, April 18, 2017),

"[a]part from the discrimination against the LGBT from society in general, the same discrimination in physical places can be experienced even from members of the LGBT. Like how some of us make fun of the parlorista gays, how we gossip about pamintas [straight-acting gays] or how we look down on fat gay men or even on gay men who we know haven't come out yet. People tend to be more cruel in social media as we can seem anonymous anyway as opposed to in physical spaces where we try to hide these biases from people as we want to project that we are civil as a people, but deep inside us, they are there."

Ali (personal communication, April 13, 2017) said that because the gays have gained a "space" in public now, this encourages those that are very "out and loud" to flamboyantly express themselves more, which puts off the more "straight-acting and discreet" ones. Jay (personal communication, April 25, 2017) said this is because even gay men are conditioned by heteronormativity and that this mentality is also seen in online gay cruising:

I've gone out with a few closeted guys from Grindr (usually from the Big 4 [top universities in the Philippines] middleclass crowd). They're always fascinated that I was out but I had an air of "decency." I would then explain my history: I was raised by parents who policed what I wore, who ensured that my voice didn't become too shrill, who reminded me that the only way to get what I wanted in life was by wearing pressed khakis and white shirt. Their acceptance was conditioned on my "decency." I doubt I would enjoy this kind of relationship with them if I had chosen to cross-dress or undergo sex-change surgery. 
I guess that still stems from the false dichotomy of parlorista vs. closeta [closeted gays], like how our parents raised us. The more closeta, the more respectable. In that way, Grindr is still very heteronormative. You only need to look at the number of "straight-acting only" profiles in there. It's sad but that takes an entire generation to correct that.

How people communicate their preferences is another matter entirely. I've found that because gay men have made strides in creating these communities online, they're more overt in stating their preferences when it comes to guys ("no effems, no chubs"). You know, I've struggled with this. On the one hand, we all have preferences when it comes to our potential partners, sexual and otherwise. But I guess what leaves a bad taste in my mouth is the entitlement that comes with stating these preferences. I'm definitely not against saying our preferences upfront, but I think profiles should still uphold respect.

Aside from the discrimination of the effeminate, sexual roles and categories were also observed to be discriminated upon within the gay spectrum. Van (personal communication, April 15, 2018) noticed that "there is such a thing as bottom-shaming. I believe this is borne out of the idea that bottoms [who assume the receiving role in anal intercourse] are effeminates and tops are more masculine, which is not necessarily true."

Asif Agha (2011), pointed out that "mediation englobes mediatization" (p.165). Mediation constitutes the "larger context and ever-present backdrop" (p. 165) of semiotic encounter in social processes that occur mostly offline and that precedes and follows mediatized objects or moments. In this case, gender performativity and policing among gay men both precede and follow this mediatized form of discrimination in gay cruising online. This performativity has always been in the context of a heterosexual matrix (Butler, 1990) that naturalized the desire for the "macho" image of a man among gay men: that being effeminate or a bottom makes a gay man more of a female than a male. The Philippines has experienced this mediation across history, with the erasure of the asogs and the babaylans in Filipino consciousness (Quintos, 2012) and " $[\mathrm{t}]$ hese divisions are reflected in clothes, gestures, language, and, more importantly, in "values" (e.g., what is "masculine" or "feminine," what is "decent" or "vulgar")" (Tan, 2001, p. 131). These social processes outside of media are then recycled and recontextualized through mediatization, for instance, through the portrayal of homosexual and lesbian sex as perversion by the MTRCB (Quintos, 2012) 
and then through the effeminate- and bottom-shaming on cruising apps like Grindr. In this manner, the "resulting social process readily remain obscure to the participants who shape it" (Agha, 2011, p. 167) such that gay men, being born into this mediated and mediatized environment that repeats and imitates the dominant conventions of this gender binary, now perpetuate this classical masculinity ideal both online and offline. Moreover,

What mediatized moments do, however, is that, when their messages reach very large populations, mediatized moments provide massively parallel inputs to recontextualization, so that a very large number of people, who may later recontextualize what they're responding to in countless ways can, nonetheless, treat fractionally congruent fragments of mediatized messages as indexical presuppositions of whatever it is they do or make. (p. 167)

When I asked my participants if they have perceived some changes in how they cruise, pick, and meet other men over time, most of them mentioned that mediatized cruising using gay apps have made it easier for them because "people come to that space knowing that we're looking for the same things: sex, friendship, even relationship. They are now provided a space that is "safe from heterosexual policing" (Nico, personal communication, October 12, 2018). Mediatized images of a gay man have also changed perceptions about them and how they can meet other men. According to Bob (personal communication, April 14, 2017), "No longer is their identity attached to Facifica Falayfay or to Roderick Paulate's (parlorista) gay characters on movies and TV. You already see Filipino gay men embracing the different levels of their masculinity and femininity." Because of this, David (personal communication, April 24, 2017) observed this change among gay men when it comes to presenting themselves and performing in online cruising:

The average gay man nowadays is more comfortable expressing himself and his interests and is less concerned with what society thinks he should look, act, and sound like. Being gay comes in a lot more different packages today than in the past. I guess it is helpful that within the gay umbrella, we have different cliques of gay men who find belongingness and support amongst other men that share similar interests.

Mac (personal communication, April 13, 2017) added:

Gay men have become more picky, more discerning. We have this option because there are a ton of options (in 
Grindr). Sifting through guys has become easier; with a click of a button, I can choose guys via "tribe," body type, and fetish. These platforms, as they try to bridge gaps and connect gay men, have also empowered us to disconnect from other gay men who do not fit our preferences.

For gay men like Paul (personal communication, April 24, 2017), this acceptance of a growing diversity of gay "target markets" has actually made him more aware of what he wanted in a partner and at the same time increased his self-acceptance and self-confidence when he post personal photos online, because to him "there is more fish in the ocean" and "when you get dropped like a hot potato the effect is less emotional."

While this is so, for some participants, gender performativity is still widely observed among gay men who cruise both online and offline. Ronan (April 18, 2017) shared:

Filipino gay men have become more confident, open, and accepting. Interestingly, while discrimination of gay men by heterosexuals is declining, discrimination among gay men remains high. Body-worship, for example, is still being used to by gay men to discriminate against other gay men.

Participants like Francis (personal communications, April 25, 2017), Adam (personal communications, April 25, 2017), and Justin (personal communications, April 23, 2017) noticed that more and more gay people go to the gym now to get a stronger muscular built and therefore be more attractive for other gay men. For Jay (personal communication, April 25, 2017), who did try to keep fit by running partly "because people on Grindr put premium on looks and physique," and where "straight-acting only" profiles abound, this is a way of remaining a closeta or closeted gay and be "respectable" and "decent" among other gay men.

Another source of discrimination among gay men is the generational divide. In my communication with the informants, there was a palpable association of younger gay men cruising as being "just about sex" while the older ones would cruise "for more meaningful connections." Ronan (personal communication, April 18, 2017) indicated this when he said:

I can only surmise that the older gay men who lived in the closet were more conservative in dealing with relationships and sex. While sex is a staple in all gay activities, I think we value relationships more than just physical intimacy. And when we are in relationships, while there are some minor lapses, we continue to value the bond between our partners. 
Compared with younger gay men, I observed that sex is a primal concern; hence the incessant desire to always look the best; to put down others who are not as endowed or affluent; to always compare exploits. They are also more carefree and careless. Wanton abandonment comes to mind especially in their sexual relationships. Multiple partners, group sex, and fleeting relationships abound. Adventurism seems to be the norm: public sex, exhibitionism, competition of sexual conquests are regular staples among a number of younger gay men. One only needs to see photos and videos in Twitter of so called "Alter" Twitter account holders to see the continuous display of sexual prowess as an identitybuilding schema.

For Tan (2001), There is no homogenous gay community as it is subdivided by class, generation, geography, and those "Westernized" or not. Because this plurality of gay identities and categories is, for a time now in studies of the Filipino gay, framed in a discourse of marginalization and discrimination, scholars like Tan expect a call or movement toward unity. But,

" $[\mathrm{m}] \mathrm{y}$ concern is that we may be looking for unity when such unity, in an organic or formal sense, may not be necessary. The diversity of communities is important because this allows for a constant revalidation, for want of a better term, of what might be a community experience, situated in history. This necessarily includes men and women who do not self-identify as gay or lesbian or bisexual or even MSM" (p. 138).

\section{The postcolonial gay men and the subscription for the Western}

Ali (personal communications, April 13, 2017) and David (personal communications, April 24, 2017) pointed out that it is the businessmen targeting the gay community that led to the emergence of new cruising places and technologies, and the eventual wider changes in gay identity and practices. David said:

I think these newer ways to meet men emerged over time because people want to explore and see what else are out there. These websites and apps were all created because there was a demand for it, and suppliers happily obliged. The gay club scene in Manila was also booming at that time 
I was starting to go out. We had a few options available to us and catered specifically to gay people.

While Ali (personal communication, April 13, 2017) believed that this commercialization of sex and love is "not just for gays, it is also the same for heteros," Ronan (personal communication, April 18, 2017) believed that this market surfaced because the "pink money showed the world that it has value and power."

But whose "world" has the gay man's market attracted? When I asked the informants how is it that gay men and their practices have started to gain more presence and acceptance in a previously restrictive society, most of them would attribute this to how Filipinos have embraced the liberal model in the Unites States, particularly indicated by the recognition of gay marriage in that part of the world, and that media have facilitated this assimilation. When I asked Jude (personal communication, April 15, 2017) to explain what he meant by "embracing Western cultures," he would point to a globalizing media environment for gay men, capitalized by countries like the US:

Embracing Western cultures means that we Filipinos are more appreciative of what the America or European countries are doing with regard to the LGBT. Our country does not censor gay themed movies, TV series, actors, etc. unlike other Southeast Asian countries like Indonesia and Malaysia who have a very strict Muslim culture. Brokeback Mountain was a huge hit here, but it was very controversial in other countries and even banned. Gay TV series like RuPauls Drag Race, Queer as Folk, Dantes Cove, Sense 8, and many more can be easily watched via live stream or downloaded in torrents.

Ronan (personal communication, April 18, 2017) also talked about this globalizing, neoliberal capitalism that seems to define gay identity and practices:

I think the start of the new millennium has ushered in a more accepting era for gay men. More celebrities and personalities came out as gay and most were welcomed by the public... Gay pride marches heightened across the globe. Image of gay bars changed: from solely featuring scantily clad men to a fun place where gay men can just enjoy the company of other gays (e.g., BED bar). Even the image (stereotypes) of gay men also changed: from screaming parloristas to every 
day professional guys who just happen to like guys as well.

Benedicto (2008a; 2008b) claims that the contemporary gay scene has been a result of the neoliberal configurations as a marketplace of gay globality and the American or Western imaginary. Certainly, as a former colony of the US, "borrowing" Western standards is too easy (Tan, 2001) especially where most of the media consumed come from Hollywood and that global American conglomerates can easily disseminate their Apple gadgets carrying apps like Scruff where announcements of the next gay circuit parties in Manila is placed or that the newest designs of Andrew Christian underwear are available online. Benedicto, using Althusser's interpellation processes, declared that while this identification of global gayness as the white gay is hegemonic, it is not without agency. Gay men particularly from the upper and middle classes subscribe to, and are not ascribed, this exportation of the American gay imaginary. He called this gay identity, gay globality.

Agha (2011) also highlighted that mediatization necessarily links social communication practices to processes of commoditization "as conditions on their possibility" (p. 163). He explains:

In linking communication to commoditization, mediatized institutions link communicative roles to positions within a socioeconomic division of labor, thereby expanding the effective scale of production and dissemination of messages across a population, and thus the scale at which persons can orient to common presuppositions in acts of communication with each other. (p. 163)

He adds:

Things and activities are treated as commodities only under specific formulations (e.g., as products, services, lifestyles, brands), and such commodity formulations are themselves disseminated through institutional genres of communication (e.g., advertising), whence they become widely known to (enregistered for) sociohistorical populations in whose activities they serve as inputs to forms of recontextualization far more varied than source commodity formulations anticipate. (p. 164)

In Philippine homosexuality literature, scholars agree that there exists the stereotype of the bakla as lower class because of their close association to the low-end salon profession (Benedicto, 2008a; Tan, 2001). On the other 
hand, it is the middle- and upper-class gay yuppies who are exposed to the globalizing gay scenes though travel and technologies, and the ones who contribute to the desire for the white male stereotype (Bendicto, 2008a). While all of my respondents fall within the middle and upper classes and it is this study's limitation that we cannot compare and contrast across classes, it is apparent that mediatized gay cruising certainly requires a certain level of affluence. And because "the exportation of the Western gay narrative and the gay White male stereotype is inseparable from wider changes in the political economy of communications and transportation technology" (Benedicto 2008a, p. 282), these upper- and middle-class gay men who have access to these technologies now develop a "double desire: a desire to be and a desire to have" (p. 290). The more they subscribe to these Western apps, the more they are exposed to the Western ideal, and vice versa. In this process, they become subjects of a global economic division of labor where they unwittingly provide free content for apps like Grindr (these apps essentially need gay men's profile to subsist) without getting any form of payment form these global corporations who earn through advertisements and subscription fees. Furthermore, gay men are reduced to market segments as they are exposed and now subscribe to Western categories such as twinks (some would characterize them as white and blonde-haired) and otters or bears (Filipinos are not typically hairy) to which more apps (like Scruff and GROWLr for bears) are positioned for.

\section{Conclusion}

The stories of these gay men have certainly illustrated the various structures and agential actions, and their interactions, surrounding gay cruising in physical and virtual spaces. There are evidence of structure determining gay identity and practices: technologies affecting multiplicity and superficiality of relationships, affording gay men to be sex-crazed, inciting an "instant" mentality, reducing gay men as markets, and technologies and physical spaces as apparatuses of capitalism and the Western-desired hegemony. Certainly, there are also manifestations of human agency: gay men's use of technologies to manage multiple relationships, to control one's choice for partners, and to enjoy the pleasures of sex; to learn about superficialities online and the desire to make one look better in person, to deal with rejections while learning how better to "market" oneself online; the expansion of the awareness of the gay spectrum and articulation of one's own identity and preference within the community and the society at large, which still favor particular groups in this spectrum.

While there is a tendency to favor or highlight one over the other, that is not my purpose, nor of any mediatization study. What can be emphasized 
is that, indeed, gay cruising is mediatized, as demonstrated in the rather confusing manifestations of gay identity and practices that I have discussed here: the intertwining of the structure and agency, the bleeding of the physical into the virtual, and vice versa, and the interactions between the online and offline. Thus, mediatization is a dialectical process in that it is both technological and social (Silverstone, 2006; 2005). It is both technological and social because while the physical spaces and mediated communications, and their use, shape, and even determine social interactions and meanings, the social actors and their interrelations in communicative practices make sense and appropriate these technologies and meanings through their own contexts and experiences. While we talk about specific physical spaces and communication technologies used for cruising by gay men, as these have become embedded into the practice of the everyday, they have also been transformed into symbols and rituals that are invisible and taken for granted in the everyday construction, circulation, and reconstruction of meanings in social life. What makes this study relevant then, is the exposure and the awareness of those that are taken for granted in this mediatization of gay cruising.

For instance, for the informants in this study it is easy to celebrate the contributions of gay technologies and social spaces to gay cruising, while they are also cautious of the accompanying disincentives. I am one with them in this recognition. But to look further, beyond the mere affordances of the technologies and the physical spaces themselves, looms the wider media environment that further complicate the mediation of gay cruising. Benedicto (2008a) argued that we are not puppets-on-strings as we consciously subscribe to the notion of the global gay and the desire for the Western.

But are we really? Can we really say that we a truly free or in control of our choices for sex or love when Grindr really only offers us 100 options at a time and that to look for more, we need to pay an additional subscription fee? Are we really empowered when Facebook, for every time we upload a photo or like another gay man's picture, enjoys free content and labor from us and then reduces us to mere marketing statistic and sells us permanently to advertisers? These advertisers then bombard us with ads on our Instagram to attend the next big gay event in Malate because it would make us feel sexy, hip, and marketable for the other gay guy who then was also prodded by the same ad to feel and do the same. With the multiplication powers of technology, then, all of us end up the same Grindr searcher, the same Facebook uploader, the same Instagram ad consumer, and the same Malate event goer. Where is freedom there? Are we really empowering ourselves as gay men, or are we no different from the heterosexuals: markets 
of neoliberalism just the same, who are not aware that they are after all, borrowing a famous quote from my favorite McLuhan (1968): "a fish who does not know it is wet?"

I did say that because the informants of my study were all of relative affluence, this may pose a methodological problem. Perhaps it was serendipitous, that their seeming homogeneity indicates that gay cruising in a mediated society—as Sonia Livingstone (2009) herself said: the mediation of everything-indeed requires relative affluence, as controlled by a neoliberal and capitalist media environment. Corollary, the disappearance of the "indigenous bakla," as lower-class and effeminate, and the emergence of the upper- and middle-class "global gay," then, is inevitable.

This study recommends, then, for future studies to see the perspectives and performances of gay men belonging to the lower social classes to be able to investigate more deeply the mediatization of gay cruising in the Philippines using the lenses of class and economics. Another recommendation for future studies is to probe into the phenomenon of the "alter" accounts, particularly on Twitter. These "alter" accounts are "alternate" or secondary accounts used by gay Twitter users to be able to express themselves, more often sexually by posting photos and videos of them naked or having sex, while remaining anonymous in a social media app that is not exclusively for gay men. This is a form of mediatized cruising and self-presentation that was mentioned by two of my participants which begs to be explored on its own.

Individual and human agency seems futile in this grand structure of neoliberalism. But as long as there are those who still cruise in movie houses, or the parloristas who pay bystanders for sexual favors, or even those who romanticize the, as my informants say it, "traditional and organic way of making meaningful and lasting relationships" still exist as a form of resistance to this neoliberal and money-based forms of modern gay cruising, then we can still continue the struggle of emancipating the Filipino gay man. 


\section{References}

Agha, A. (2011). Meet mediatization. Language \& Communication, 31(3), 163-70.

Austria, F. (2004). JUDING_GERZI ONLINE: Insights into the potentials of virtual communities on Yahoo! Groups in addressing the challenges of being gay in the Philippines. Plaridel: A Philippine Journal of Communication, Media, and Society, 1(2), 21-48.

Austria, F. (2007). Gays, the Internet, and freedom. Plaridel: A Philippine Journal of Communication, Media, and Society, 4(1), 47-76.

Baytan, R. (2015). The death of gay Malate: One-time gay capital of the Philippines. Kyoto Review of Southeast Asia, 18. Retrieved from https://kyotoreview.org/issue-18/death-gay-malatephilippines/

Benedicto, B. (2008a). Desiring sameness: Globalization, agency, and the Filipino gay imaginary. Journal of Homosexuality, 55(2), 274-311.

Benedicto, B. (2008b). The haunting of gay Manila: Global space-time and the specter of kabaklaan. GLQ: A Journal of Lesbian and Gay Studies, 14(2-3), 317-38.

Butler, J. (1990). Gender trouble: Feminism and the subversion of identity. New York: Routledge.

Collins, D. (2005). Identity, mobility, and urban place-making: Exploring gay life in Manila. Gender and Society, 19(2), 180-198.

Dulay, D. (2018, February 6). Generation swipe: how dating apps can ruin lives. The Manila Times. Retrieved from https://www.manilatimes.net/generation-swipe-dating-apps-can-ruin-lives/378401/

Gergen, K. J. (1991). The saturated self: Dilemmas of identity in contemporary life. New York: Basic Books

Hepp, A. (2013). The communicative figurations of mediatized worlds: Mediatization research in times of the "mediation of everything." European Journal of Communication, 28(6), 615-629.

Hull, P., Mao, L., Prestage, G., Zablotska, I., de Wit, J., \& Holt, M. (2016). The use of mobile phone apps by Australian gay and bisexual men to meet sex partners: An analysis of sex-seeking repertoires and risks for HIV and STIs using behavioural surveillance data. Sexually Transmitted Infections 0,1-6. doi:10.1136/sextrans-2015-052325.

Lehmiller, J. J. \& loerger, M. (2014). Social networking smartphone applications and sexual health outcomes among men who have sex with men. PLOS ONE, 9(1), e86603. doi:10.1371/journal. pone.0086603.

Livingstone, S. (2009). On the mediation of everything. Journal of Communication, 59(1), 1-18.

McLuhan, M. (1964). Understanding media. London: Routledge and Kegan Paul.

Pertierra, R., Ugarte, E. F., Pingol, A., Hernandez, J., \& Dacanay, N. L. (2002). TXT-ING selves: Cell phones and Philippine modernity. Manila, the Philippines: De La Salle University Press.

Postman, N. (1970). The reformed English curriculum. In A. C. Eurich (Ed.), High school 1980: The shape of the future in American secondary education (pp. 160-168). New York: Pitman.

Quintos, J. (2012). A glimpse into the Asog experience: A historical study on the homosexual experience in the Philippines. Plaridel: A Philippine Journal of Communication, Media, and Society, 9(2), 155-170.

Race, K. (2015). "Party and play": Online hook-up devices and the emergence of PNP practices among gay men. Sexualities, 18 (3), 253-275.

Silverstone, R. (2005). Mediation and communication. In C. Calhoun, C. Rojek, and B. Turner (Eds.), Handbook of Sociology (pp. 188-207). London: Sage. 
Silverstone, R. (2006). Domesticating domestication: Reflections on the life of a concept. In T. Berker, M. Hartmann, Y. Punie, and K. J. Ward, (Eds.), Domestication of media and technology (pp. 229-248). Maidenhead, UK: Open University Press.

Solis, R. J. C. (2007). Texting love: An exploration of text messaging as a medium for romance in the Philippines. M/C Journal, 10(1). Retrieved from http://journal.media-culture.org.au/0703/05-solis. php.

Tan, M. L. (2001). Survival through pluralism. Journal of Homosexuality, 40(3-4), 117-142.

RANDY JAY C. SOLIS is an assistant professor at the University of the Philippines, Diliman. Currently, he is a PhD Candidate at the School of Journalism and Communication at The Chinese University of Hong Kong. His research interests include new media, development and health communication, and children and gender studies. His research has been published in the Chinese Journal of Communication; $M / C$ Journal; Pilipinas: A Journal of Philippine Studies; and Plaridel: A Philippine Journal of Communication, Media, and Society. (Corresponding author: randyjaysolis@gmail.com) 